\title{
Fish consumption and consumer awareness aspects of possible mycotoxin contamination in fish in Curitiba-PR, Southern Brazil
}

Aspectos do consumo de pescado e da conscientização de consumidores quanto à possível contaminação por micotoxinas no pescado da região de Curitiba-PR, sul do Brasil

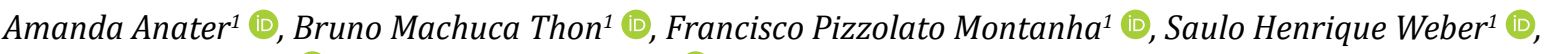
Deivid Roni Ribeiro ${ }^{2}$ (1), Cláudia Turra Pimpão ${ }^{1}$ (D)

\section{A B S T R A C T}

The global per capita consumption of fish reached a record of $20.5 \mathrm{~kg}$ in 2018, thus demonstrating the sector's importance. A potential risk to consider when consuming fish is the indirect intake of mycotoxins by humans when consuming fish from intensive fish farming fed with potentially contaminated mycotoxins. The aim of this study was to evaluate fish consumption and consumer awareness of possible mycotoxin contamination in Curitiba, Paraná, Brazil. The information was obtained through a questionnaire applied at supermarkets in 5 different city regions, obtaining 358 respondents. Descriptive analysis was performed on the data, followed by Spearman's correlation analysis between the responses. It was observed that demographic data (e.g., age, gender, and social class) significantly influenced fish consumption frequency. Thus, $64.80 \%$ of respondents preferred tilapia meat over other fish species, $89.91 \%$ of people are unaware of mycotoxins, and $93.95 \%$ of people do not know what damage mycotoxins cause in human and animal health, and $86.17 \%$ of people did not know about any disease related to fish consumption. Schooling had a significant correlation with the aforementioned issues, demonstrating that lower educational levels negatively influence the perception of illnesses caused by food. The most consumed fish is farm-raised tilapia and the consequent possibility of mycotoxin exposure. Respondents are unaware of the possible mycotoxin presence in fish and their impact on human health.

Keywords: food safety; Nile tilapia; Oreochromis niloticus; pisciculture; toxins.

\section{RE S U M 0}

O consumo per capita global de pescado atingiu seu recorde de $20,5 \mathrm{~kg}$ em 2018, demonstrando a importância do setor. Um potencial risco a ser considerado no consumo de pescado é a ingestão indireta de micotoxinas pelos humanos por meio do consumo de peixes provenientes de piscicultura intensiva, alimentados com ração potencialmente contaminada por micotoxinas. O objetivo foi avaliar aspectos do consumo do pescado e da conscientização dos consumidores quanto à sua possível contaminação por micotoxinas em Curitiba, Paraná, Brasil. As informações foram obtidas com um questionário aplicado em supermercados de cinco regiões distintas da cidade, obtendo um total de 358 respondentes. Realizou-se análise descritiva dos dados, seguida de análise de correlação de Spearman entre as respostas. Observou-se que dados demográficos influenciaram significativamente a frequência de consumo de pescado (ex. idade, gênero e classe social). Um total de $64,80 \%$ dos entrevistados preferiu carne de tilápia em detrimento de outras espécies de peixes, $89,91 \%$ das pessoas desconhecem o que são micotoxinas, $93,95 \%$ não sabem quais danos as micotoxinas causam à saúde humana e animal e $86,17 \%$ não conheciam nenhuma doença relacionada ao consumo de pescado. A escolaridade teve correlação significativa com as questões citadas acima, demonstrando que níveis de escolaridade menores influenciam negativamente a percepção sobre doenças transmitidas por alimentos. O pescado mais consumido é a tilápia de cultivo, indicando a possibilidade de exposição a micotoxinas. Os respondentes desconhecem a possibilidade da presença de micotoxinas em pescado e seus impactos à saúde humana.

Palavras-chave: segurança alimentar; tilápia do nilo; Oreochromis niloticus; piscicultura; toxinas.

\footnotetext{
${ }^{1}$ Pontifícia Universidade Católica do Paraná - Curitiba (PR), Brazil.

${ }^{2}$ Universidade Federal do Paraná - Curitiba (PR), Brazil.

Correspondence address: Amanda Anater - Imaculada da Conceição street, 1155 - Prado Velho - CEP: 80215-901 - Curitiba (PR), Brazil. E-mail: amanda_anater@hotmail.com

Conflicts of interest: the authors declare that there are no conflicts of interest.

Funding: Coordination for the Improvement of Higher Education Personnel (CAPES) and Pontifical Catholic University of Paraná (PUCPR). Received on: 12/29/2020. Accepted on: 05/16/2021.
}

https://doi.org/10.5327/Z217694781023

This is an open access article distributed under the terms of the Creative Commons license. 


\section{Introduction}

Fishing and aquaculture are important sources of food worldwide; this importance tends to grow since the annual global per capita consumption has increased and reached a record $20.5 \mathrm{~kg}$ in 2018 (FAO, 2020). These activities are considered by the Food and Agriculture Organization of the United Nations (FAO) as strategic for worldwide sustainable food security because they can provide protein sources of high nutritional quality (Bombardelli et al., 2005; FAO, 2020).

A factor contributing to the growing appreciation of this type of food is the perception by consumers regarding its positive aspects: easily digestible, high protein, and low caloric value, compared with other protein foods available in the market (Gonçalves et al., 2008).

However, as in the entire food production chain, more specifically of animal origin, this growth must occur orderly and sustainably, guaranteeing quality and origin traceability. From the quality point of view, one of the aspects to be controlled is contaminants. Among them, toxins produced by fungi present relative importance since they can be found in the production and consumption cycle (Montanha et al., 2018; Pietsch, 2020).

With the increase in the global demand for fish, intensive fish farming has been gaining space concerning fishing or extractivism (FAO, 2020). This activity is crucial because it aligns with some points of the Sustainable Development Goals developed by the United Nations (ONU, 2015) including eradicating hunger, promoting quality health, sustainable production, and consumption, and conserving and sustainably using water resources, especially marine ones.

Thus, to achieve high productivity on a large scale, the use of balanced feeds is indispensable; so, like in other intensive animal production systems, animals are fed with feeds that have potentially been contaminated by mycotoxins (Atayde et al., 2014). This is demonstrated in studies that evaluated the contaminant presence in fish feed (Barbosa et al., 2013; Olorunfemi et al., 2013; Gonçalves et al., 2016; Mohamed et al., 2017), which reported individual mycotoxin concentrations ranging from 0.04 to $341.99 \mu \mathrm{g} / \mathrm{kg}$, in addition to co-occurrence, that is, contamination by more than one class of mycotoxin in the same sample (Marijani et al., 2017). If mycotoxin consumption via feed occurs, there is a risk of compound deposition in the final product, the so-called carry-over effect (Montanha et al., 2018), potentially exposing the final consumer to these contaminants (Abd-Elghany and Sallam, 2015).

Due to this cross-contamination possibility, countries that stand out in animal production, such as Brazil, which is the world's fourth-largest producer of Nile tilapia (Oreochromis niloticus) (ABP, 2021), must implement appropriate prevention measures to minimize or trace possible contaminations in animal feed, providing more excellent food safety and quality of the final product. Therefore, this study aimed to evaluate fish consumption and consumer awareness regarding possible food contamination by mycotoxins in Curitiba, Paraná, Southern Brazil.

\section{Materials and Methods}

This study was approved by the Research Ethics Committee of the Pontifical Catholic University of Paraná (PUCPR) under the report number 2.310.264, 2nd version.

The experimental design had a cross-sectional observational character, in which a sample of consumers from supermarkets in the city of Curitiba-PR was interviewed inside these establishments. All interviewees were above 18 years old at the time of the interview. When initially approaching consumers, the informed consent form was presented for participants' knowledge, with subsequent signatures to authorize the disclosure of the study results.

The questionnaire used in this study was adapted from Gonçalves et al. (2008) and Flores et al. (2014), and its final version contained 17 multiple-choice questions addressing aspects related to educational level, farmed fish consumption, and knowledge about mycotoxins. All questionnaires were applied to customers from previously selected supermarkets in five regions (i.e., north, south, east, west, and central) of Curitiba, Paraná.

The initial selection of supermarkets was performed through an Internet search using the Google ${ }^{\circledR}$ search platform. The terms used for the search and selection were adapted from Moutinho et al. (2015): "supermarket" + "Curitiba" + "PR" + "region."

Accordingly, the search platform returned 130 results, which were listed, numbered, and separated by region, using Excel ${ }^{\circledR}$ software. Approximately $10 \%$ of the establishments in each region were randomly selected using the "random" command. Out of the total 130 markets, 12 markets were selected for this study.

The questionnaire was applied randomly to customers inside the supermarkets in different sectors, and the manager previously approved this study. Initially, the customers were questioned about their age, and only when the interviewee was above 18 years old, the rest of the questionnaire was applied.

For the data presentation, descriptive statistics were used, with absolute and relative numbers for each alternative concerning the number of interviewees or respondents to the specific questions.

Spearman's correlation test was applied to evaluate the possible correlations between the qualitative variable responses. For the correlation analysis, the software Statgraphics Centurion, version XVI for Windows $^{\circledR}$, was used. The significance level adopted was $5 \%(\mathrm{p}<0.05)$ (Petrie and Watson, 2009).

\section{Results}

\section{Demographic data}

The questionnaire was applied to 358 participants, with the following distribution among the regions of Curitiba: north $(n=70)$, east $(\mathrm{n}=70)$, south $(\mathrm{n}=71)$, west $(\mathrm{n}=72)$, and central region $(\mathrm{n}=75)$.

Of the 358 participants, $54.19 \%(n=194)$ were females and $45.81 \%$ $(\mathrm{n}=164)$ were males. The mean, followed by the standard deviation 
$( \pm \mathrm{SD})$ of age for males was $41.85 \pm 16.73$ years old and for females was $39.77 \pm 16.22$ years old. The mean weight $( \pm \mathrm{SD})$ for males was $79.76 \pm$ $13.71 \mathrm{~kg}$ and for females $68.83 \pm 12.60 \mathrm{~kg}$. The mean $( \pm \mathrm{SD})$ height of the men interviewed was $1.73 \pm 0.07 \mathrm{~m}$ and for women was $1.62 \pm 0.07 \mathrm{~m}$.

Education was divided into incomplete elementary school (IES), complete elementary school (CES), incomplete high school (IHS), complete high school (CHS), incomplete higher education (IHE), and complete higher education (CHE). The results obtained from the schooling of the people interviewed $(n=358)$ were as follows: $9.78 \%(n=35)$ of the interviewees had IES, $12.29 \%(\mathrm{n}=44)$ had CES, 3.63\% $(\mathrm{n}=13)$ had IHS, 36.03\% ( $\mathrm{n}=129)$ had CHS, 6.98\% $(\mathrm{n}=25)$ had IHE, 5.87\% $(\mathrm{n}=21)$ had CHE, and $25.42 \%(n=91)$ preferred not to answer about schooling.

The social classes of the interviewees were divided into class A, B, C, D, or E, according to the 2017 definition of the Brazilian Institute of Geography and Statistics (IBGE, 2017), which characterizes class $\mathrm{A}$ as people who have a monthly income equal to or greater than $\mathrm{R} \$ 18,740.01$, class B with a monthly income between $\mathrm{R} \$ 9,370.01$ and $\mathrm{R} \$ 18,740$, class $\mathrm{C}$ with a monthly income ranging from $\mathrm{R} \$ 3,748.01$ to $\mathrm{R} \$ 9,370$, class $\mathrm{D}$ with a monthly income of $\mathrm{R} \$ 1,874.01$ to $\mathrm{R} \$ 3,748$, and class $\mathrm{E}$ with a monthly income equal to or less than $\mathrm{R} \$ 1,874$.

Respondent distribution $(\mathrm{n}=358)$ within social classes was as follows: class $\mathrm{A}=1.12 \%(\mathrm{n}=4), \mathrm{B}=2.79 \%(\mathrm{n}=10), \mathrm{C}=20.95 \%(\mathrm{n}=75)$, $\mathrm{D}=23.74 \%(\mathrm{n}=85)$, and $\mathrm{E}=49.16 \%(\mathrm{n}=176)$, and respondents who preferred not to answer accounted for $2.23 \%(n=8)$ of the total. Table 1 presents the respondents' education and social class data.

Regarding interviewees' occupations ( $\mathrm{n}=358), 75$ different professions were registered, among which the six with the highest frequency were as follows: salesperson at $11.17 \%(\mathrm{n}=40)$, retiree and trader at $5.87 \%$ ( $\mathrm{n}=21)$, student at $4.75 \%(\mathrm{n}=17)$, housewife and taxi driver at $3.91 \%$ $(\mathrm{n}=14)$, and others at $64.53 \%(\mathrm{n}=231)$ of the total responses (Table 1$)$.

There were 50 neighborhoods in Curitiba, the ones with the highest response frequency were as follows: Cidade Industrial de Curitiba at $16.48 \%(\mathrm{n}=59)$, Sítio Cercado at $12.01 \%(\mathrm{n}=43)$, Santa Felicidade at $6.98 \%(n=25)$, Cajuru at $5.87 \%(n=21)$, Mercês with $3.35 \%(n=12)$, and others at $55.31 \%(\mathrm{n}=198)$.

\section{Questionnaire}

In general, the questions were divided into the following three sections: consumption characteristics and preferences, the criteria for choosing fish, and the level of knowledge regarding possible contaminations and diseases acquired through the consumption of farmed fish.

\section{Fish consumption characteristics and preference}

From a total of 358 respondents, $71.23 \%(\mathrm{n}=255)$ stated that they were responsible for the household purchases, and the remaining $28.77 \%(n=103)$ stated that they made sporadic purchases and did not make decisions about the products to be purchased. This variable had a significant $(\mathrm{p}<0.05)$ positive correlation with the age of the interviewee $(r=0.3052)$, generally the older people in the house are responsible for choosing and buying the products. In addition, there was a significant $(\mathrm{p}<0.05)$ positive correlation with the female gender $(\mathrm{r}=0.8362)$, thus demonstrating that women are the main ones in charge of purchasing decisions in supermarkets.

Regarding the type of diet, $3.07 \%(n=11)$ of the respondents called themselves strict vegetarians, in other words, who do not eat animal protein. These respondents did not answer the questionnaire since the other questions had to do with fish consumption and purchase.

All the remaining questions were asked for the 96.93\% $(n=347)$ of respondents who were nonvegetarians. This definition did not show any significant correlation $(\mathrm{p}>0.05)$ with the other results obtained in the questionnaire.

The primary motivation for consuming fish was its pleasant taste since $70.03 \%(n=243)$ of respondents answered the alternative taste as the main reason for consumption. The nutritional quality was the reason that $12.97 \%(n=45)$ of respondents eat fish; the easy access to fish was the reason for $2.88 \%(\mathrm{n}=10)$ of the respondents to consume it; $2.31 \%(\mathrm{n}=8)$ of respondents eat to vary their menu; $0.86 \%(n=3)$ of respondents eat because of the affordable cost of different fish species, which represents the same proportion of people who eat fish because of religion.

Still, $6.63 \%(n=23)$ of the people answered at least two alternatives (e.g., nutritional quality and taste of the meat, or quality

Table 1 - Distribution of respondents' answers according to education, social class, and profession.

\begin{tabular}{|l|c|c|c|c|c|}
\hline Variable & $\%($ total $\mathbf{n})$ & Variable & $\%$ (total n) & Variable & Salesperson \\
\hline IES & $9.78(35)$ & Class A & $1.12(4)$ & Retiree & $5.87(21)$ \\
\hline CES & $12.29(4)$ & Class B & $2.79(10)$ & Trader \\
\hline IHS & $3.63(13)$ & Class C & $20.95(75)$ & Student \\
\hline CHS & $36.03(129)$ & Class D & $23.74(85)$ & Housewife & $3.75(17)$ \\
\hline IHE & $6.98(25)$ & Class E & $49.16(176)$ & Taxi driver \\
\hline CHE & $5.87(21)$ & PNA & $2.23(8)$ & Others \\
\hline PNA & $25.42(91)$ & & & $64.91(14)$ \\
\hline
\end{tabular}

n: number; IES: incomplete elementary school; CES: complete elementary school; IHS: incomplete high school; CHS: complete high school; IHE: incomplete higher education; CHE: complete higher education; PNA: preferred not to answer. 
and accessibility). In comparison, $0.58 \%(n=2)$ of respondents cited a combination of three factors for consuming fish (i.e., nutritional quality, accessibility, and taste of the meat). Only $2.88 \%$ $(n=10)$ of the respondents were unwilling or unable to answer this question. There was no significant correlation $(p>0.05)$ of fish consumption motivations with the other questions and demographic data.

With $36.61 \%(n=127)$ of the answers, the most significant proportion of respondents reported consuming fish only once a month, while $24.50 \%(n=85)$ of respondents eat once a week. The option "rarely or during religious celebrations" appeared in $20.17 \%(n=70)$ of the answers; the option "two or three times a week" appeared in $11.24 \%$ $(n=39)$ of the cases; $2.02 \%(n=7)$ of the respondents eat more than three times a week, and only $0.58 \%(\mathrm{n}=2)$ of the respondents eat every day. Also, $4.03 \%(n=14)$ of the people indicated that they do not consume fish. The percentage of unwilling or unable to answer was $0.86 \%$ $(\mathrm{n}=3)$ (Figure 1).

The frequency of consumption correlation and age of the participants was significant $(\mathrm{p}<0.05)$ and positive $(\mathrm{r}=0.1291)$, indicating a slight tendency that the higher the age, the higher the frequency of fish consumption.

The data collected in the sequence were related to frequency of fish purchasing for home consumption. In this regard, $36.31 \%(\mathrm{n}=126)$ of the participants stated that they buy it once a month, $21.90 \%(n=76)$ do not buy it at all, $17.29 \%(\mathrm{n}=60)$ buy it once a week, $15.56 \%(\mathrm{n}=54)$ buy it rarely or just at religious celebrations, $7.78 \%(\mathrm{n}=27)$ buy it two to three times a week, $0.29 \%(\mathrm{n}=1)$ buy it more than three times a week, and no participant replied that they buy it daily. The nonrespondents or those who did not know how to answer were $0.86 \%(n=3)$ of the total.

The frequency of fish acquisition showed a significant $(\mathrm{p}<0.05)$ and positive correlation $(r=0.1142)$ with interviewees' place of residence. Residents from the northern and central regions of Curitiba buy fish to consume at home more often than those who live in the other regions of the city. There was a significant correlation $(\mathrm{p}<0.05)$ between the frequency of fish purchasing and the age of the inter-

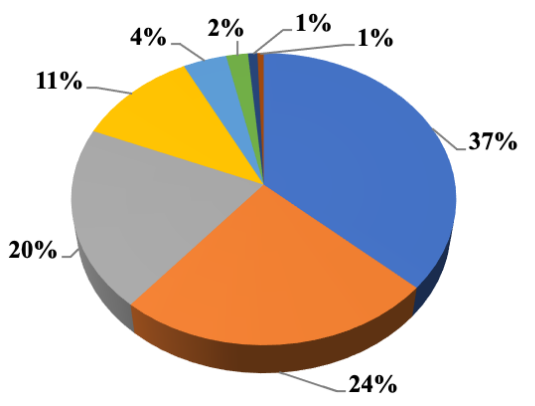

- Once a month

- Once a week

Rarely/celebrations

$\square$ Two or three times a week

- Do not consume fish

$\square$ More than three times a week

- Preferred not to answer

n Everiday

Figure 1 - Distribution of respondents' answers regarding the frequency of fish consumption. viewee $(r=0.1793)$, showing that the older the person, the more frequently they buy fish for home consumption, which is in line with the higher frequency of fish consumption mentioned above.

Depending on where the fish is bought, the general preference was for supermarkets, with a majority of $41.79 \%(n=145)$, followed by $31.41 \%(n=109)$ of people who said they prefer to buy fish from fishmongers; fish markets and fish-pond purchases had the same percentage of respondents, both at $8.07 \%(n=28)$. It is worth mentioning that $2.88 \%(n=10)$ of the interviewees answered that they had private suppliers such as neighbors or relatives that produce or raise fish on their property, $5.19 \%(\mathrm{n}=18)$ of people said they did not buy fish, and $2.59 \%(n=9)$ were the percentages of those who preferred not to answer or did not know the answer (Figure 2). This variable did not show any significant correlation $(\mathrm{p}>0.05)$ with other variables.

Regarding the fish preparation preference, almost half of the interviewees $(44.67 \%, \mathrm{n}=155)$ said they prefer fried fish; $19.88 \%(\mathrm{n}=169)$ of the interviewees prefer baked fish; $8.93 \%(n=31)$ of the interviewees prefer battered fish; $8.65 \%(\mathrm{n}=30)$ of the interviewees prefer grilled, which is the same proportion of preference for raw fish $(8.65 \%, \mathrm{n}=30)$, and those who prefer to eat fish in stew represented $8.36 \%(n=29)$ of the respondents. Finally, only $0.86 \%(n=3)$ of the interviewees said they did not go for the prepared way. There was no significant correlation $(\mathrm{p}>0.05)$ between preparation, the other questions, and demographic data.

With more than half of the answers, tilapia was the fish of preference for $64.84 \%(n=225)$ of respondents, followed by salmon for $16.14 \%(n=56)$ of respondents, pintado for $5.76 \%(n=20)$ of respondents, tucunaré for $5.48 \%(\mathrm{n}=19)$ of respondents, and finally tambaqui for $4.90 \%(\mathrm{n}=17)$ of respondents The remaining $2.88 \%$ $(\mathrm{n}=10)$ of respondents said that they prefer other species, such as hake, sole, and mullet, but these species are not raised in captivity and were beyond the research scope. The preference of a particular fish species did not show a significant correlation ( $p>0.05)$ with any other variable evaluated. Figure 3 shows the preference distribution of fish species for consumption.

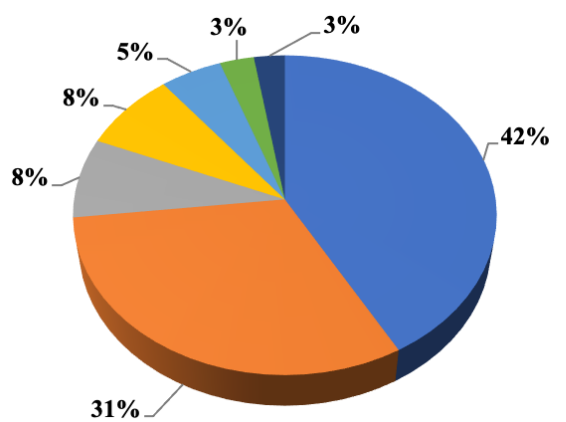

- Supermarkets

- Fishmonger

Fish markets

Fish-pond purchases

Do not buy

$\square$ Private fish suppliers

- Preferred not to answer

Figure 2 - Distribution of the respondents' answers regarding their preferred places to buy fish. 


\section{Criteria for choosing fish}

The first item evaluated in this section was which fish species the consumer acquires at the moment of purchase; even though it is similar to the question regarding the preference for the consumption of a specific species, the consumer may decide to purchase a different species due to other factors such as price, for example.

The most frequently purchased fish was tilapia. Notably, $47.55 \%$ $(n=165)$ of the interviewees affirmed that it is the fish most frequently purchased; $10.09 \%(n=35)$ of the interviewees said that they preferred to buy salmon; $3.17 \%(\mathrm{n}=11)$ of the interviewees preferred pintado, a proportion identical to that for tucunaré, with $3.17 \%(n=11)$ of the answers; $2.88 \%(n=10)$ of the interviewees preferred tambaqui; and finally, 33.14\% ( $\mathrm{n}=115)$ preferred other species (as mentioned above) (Figure 4). The purchase preferences regarding the species were not correlated with the other variables ( $p>0.05)$.

Regarding the way fish is purchased, about two-thirds of the respondents $(68.88 \%, \mathrm{n}=239)$ stated that they prefer to buy fresh/ chilled fish, $27.95 \%(n=97)$ prefer to buy frozen fish, and $0.29 \%$ $(\mathrm{n}=1)$ preferred to buy salted, canned and smoked fish. A total of $2.02 \%(n=7)$ of the respondents stated that they do not buy fish in any form, while $0.29 \%(\mathrm{n}=1)$ preferred not to answer. This variable showed no significant correlation $(\mathrm{p}>0.05)$ with the other questions and demographic data.

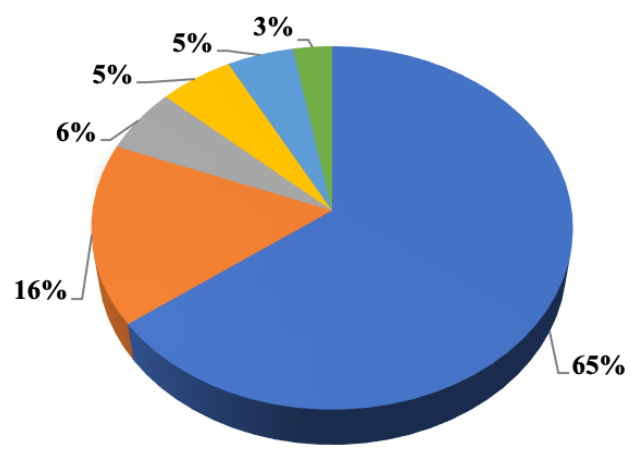

- Tillapia

- Salmon

- Pintado

" Tucunaré

- Tambaqui

- Others

Figure 3 - Distribution of the respondents' answers regarding the preference of fish for consumption.

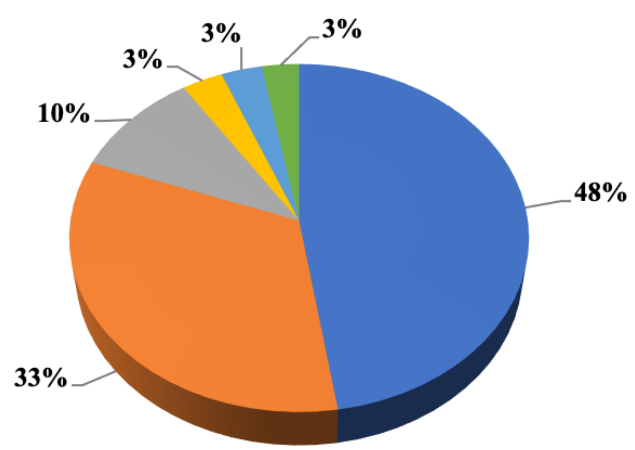

- Tilapia

athers

- Salmon

- Pintado

- Tucunaré

Tambaqui

Figure 4 - Distribution of the respondents' answers regarding the acquisition of fish.
Regarding fish presentation, most of the respondents $(61.67 \%$, $\mathrm{n}=214)$ stated their preference for a filet; $23.63 \%(\mathrm{n}=82)$ of the respondents prefer whole fish, while $9.80 \%(\mathrm{n}=34)$ of the respondents showed a preference for whole gutted fish, with a smaller portion of respondents $(4.90 \%, \mathrm{n}=17)$ stating that they prefer the cut in slices. There was no significant correlation $(\mathrm{p}>0.05)$ of presentation with the other questions and demographic data.

When asked how they evaluate the fish quality to purchase, $59.08 \%$ $(n=205)$ of the respondents said it is by the general appearance of the product; $19.60 \%(n=68)$ of the respondents said it is more than one factor (i.e., by appearance and shelf life, or appearance and price, or shelf life and freshness); $12.39 \%(\mathrm{n}=43)$ of the respondents said it is by the expiration date on the package; $3.46 \%(n=12)$ of the respondents answered by using factors other than the ones provided (i.e., eyes, aroma, and origin); and $1.15 \%(n=4)$ of the respondents answered that they evaluate by shelf life. Finally, $4.32 \%(n=15)$ of the respondents said that they do not buy fish, so they do not know how to evaluate the quality issue. There was no significant correlation $(p>0.05)$ between the other questions and the demographic data.

Regarding the perception of fish price in supermarkets, $59.94 \%$ $(n=208)$ of the interviewees think the price is high; $10.66 \%(n=37)$ of the interviewees said they think it is too high; $9.22 \%(n=32)$ of the interviewees said that the price charged by supermarkets is low; $7.20 \%$ $(n=25)$ of the interviewees think the price is regular; and $0.58 \%(n=2)$ of the people interviewed think it is very cheap. In this question, $12.39 \%$ $(\mathrm{n}=43)$ did not want to or did not know how to answer. There was a significant correlation $(\mathrm{p}<0.05)$ between the perception of fish price and interviewee gender, this correlation being positive $(r=0.1357)$ with males, thus demonstrating that men, in contrast to women, tend to perceive fish price in the market as more expensive. There were no significant correlations $(p>0.05)$ between the perception of fish price and consumer education and social class/income, showing that, in general, the interviewed population considers the fish to be expensive.

\section{Consumers' knowledge regarding possible contaminants in fish}

The first question of this session was related to consumer opinion about the decrease of possible contaminants in fish after cooking; they should answer yes if they think that cooking decreases contaminant levels and no otherwise. With this, $56.77 \%(n=197)$ of the respondents answered no that fish does not cease to present contamination risks, while $40.63 \%(n=141)$ of the respondents answered yes that fish ceases to present contamination risks after cooking for consumption. Only $2.59 \%(n=9)$ of the respondents did not know (Figure 5). This question also showed no significant correlation ( $p>0.05$ ) with the other questions and demographic data.

Regarding knowledge about possible diseases acquired by eating fish, the great majority, $86.17 \%(n=299)$, answered that they do not know which diseases can be caught, while $12.68 \%(\mathrm{n}=44)$ answered that they know some diseases. Only $1.15 \%(n=4)$ of the respondents preferred not to answer. 
The knowledge of possible diseases acquired through fish consumption showed a significant $(\mathrm{p}<0.05)$ and negative correlation $(r=-0.2039)$ with the level of education of the interviewees, showing that people with lower educational levels (i.e., IES, CES, and IHS) understand this as riskless. There was also a significant correlation $(\mathrm{p}<0.05)$ of this question with the social class of the interviewees $(r=-0.1565)$, showing that people belonging to lower social classes (i.e., D and $\mathrm{E}$ ) understand this as riskless.

The second-to-last question verifies the respondents' level of understanding of mycotoxin existence. Almost $90 \%$ of the respondents $(89.91 \%, \mathrm{n}=312)$ did not know what mycotoxins are, while $8.93 \%$ $(\mathrm{n}=31)$ said they know mycotoxins. Respondents who preferred not to answer totaled $1.15 \%(n=4)$ (Figure 6).

There was a significant $(\mathrm{p}<0.05)$ and negative $(\mathrm{r}=-0.1559)$ correlation between knowledge about what mycotoxins are and interviewees' educational levels, showing that people with lower educational levels tend not to know what mycotoxins are. As with the previous question, social class significantly impacts too $(\mathrm{p}<0.05)$, with a negative correlation $(r=-0.1550)$ regarding the knowledge about what mycotoxins are. In other words, individuals from lower social classes (D and $\mathrm{E}$ ) tend not to understand what these toxins are.

The last question asked to the interviewee was about the possible toxic effects that mycotoxins can cause on humans. A total of $93.95 \%$ $(n=326)$ of the people said they did not know what these effects are, while only $4.90 \%(n=7)$ of the people said they were aware of the

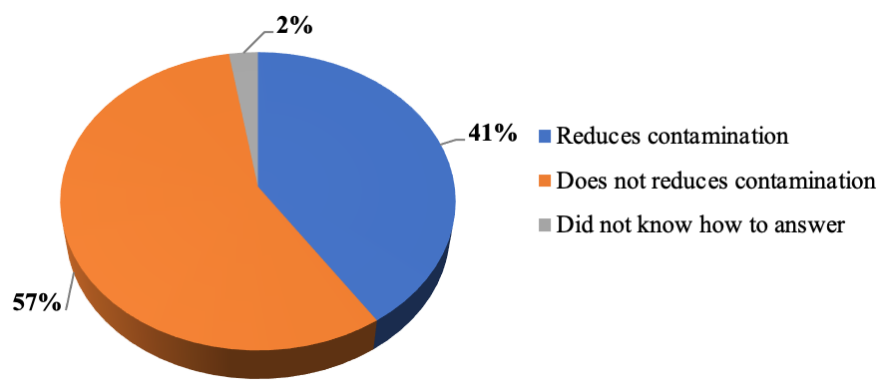

Figure 5 - Distribution of the respondents' answers regarding the perception about reducing possible contaminants by cooking the fish.

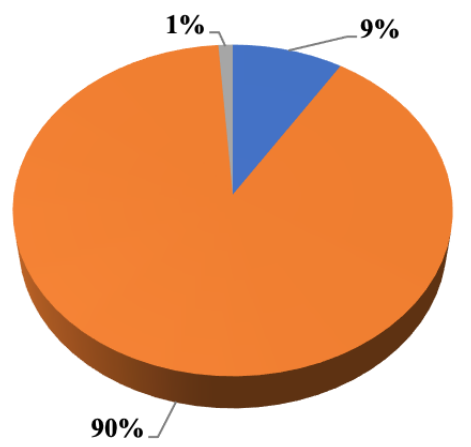

\section{- Know}

- Do not know

m Preferred not to answer

Figure 6 - Distribution of interviewees' responses concerning knowledge about mycotoxins. effects caused by exposure to these toxins. Only $1.15 \%(n=4)$ of the people preferred not to answer (Figure 7).

In this last question, there was a significant $(\mathrm{p}<0.05)$ and negative correlation $(r=-0.1243)$ with the interviewee's educational level, showing that people with lower education levels (i.e., IES, CES, and IHS) tend not to know about mycotoxins' possible deleterious effects on human health.

\section{Discussion}

From a consumption profile perspective, some studies have also evaluated this variable in population samples from different regions of Brazil. Maciel et al. (2013), when interviewing 1,966 people from different campuses of the University of São Paulo, reported that $27.11 \%$ of the respondents consumed fish only once a week, $25.94 \%$ from two to three times a month, $17.40 \%$ consumed it once a month, and $14.80 \%$ rarely.

Another study that characterizes fish consumption interviewed people in all Brazilian regions (Lopes et al., 2016), and the authors classified as low the average frequency of fish consumption by Brazilians, citing that $39.52 \%$ of the respondents consume from once to twice a month, while $30.65 \%$ eat at least once a week.

Both cited works differ in some point from this study regarding the frequency of fish consumption. The percentage of people who consume once a month was more than double that was found by Maciel et al. (2013), while the percentage of people who consume at least once a week was $6 \%$ points lower than that was found by Lopes et al. (2016). This shows that, in general, the characterization of fish consumption in a population tends to be complex since it involves socioeconomic factors, consumption patterns, and personal and regional preferences (Maciel et al., 2012).

The low frequency of fish consumption found in this type of work reflects the low annual per capita consumption of fish by Brazilians, which is around $9 \mathrm{~kg} /$ year (FAO, 2019), considered low by the FAO, which recommends at least $12 \mathrm{~kg} /$ person/year. The consumption of fish in Brazil is also low compared with the global average, which is $20 \mathrm{~kg} /$ person/year, that is, there is still room to increase the participation of fish on the Brazilian table.

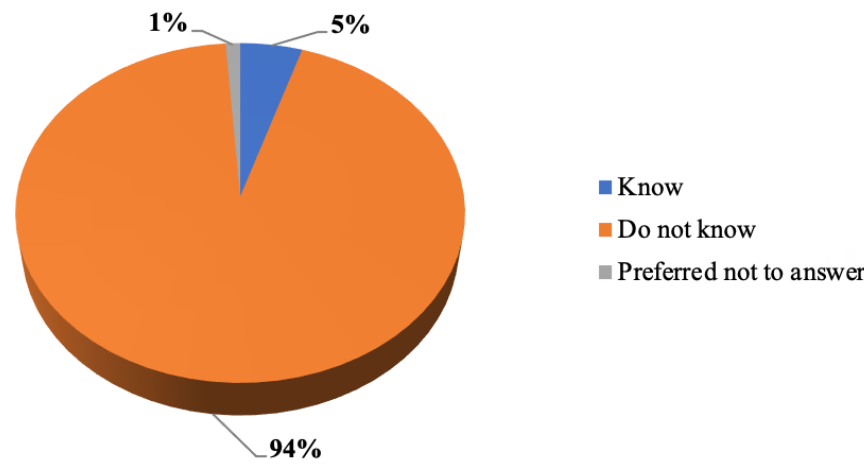

Figure 7 - Distribution of respondents' answers regarding knowledge of mycotoxins' possible deleterious effects on human health. 
This low consumption seems to have a significant cultural factor in Brazilian territory since the variation among regions is significant according to the 2017 and 2018 Household Budget Survey (IBGE, 2020), which show that the per capita acquisition of fish in the Northern Region was $9.85 \mathrm{~kg} /$ year against $1.04 \mathrm{~kg} /$ year in the Southern Region. Factors such as the constant supply of fish with attractive prices, in addition to the diversity and ease of acquisition, probably influence this higher consumption in the Northern Region of Brazil (Lopes et al., 2016).

The preference for the fish species is also regionally influenced. Flores et al. (2014) conducted a preference survey in the state of Tocantins, with tambaqui being one of the most consumed species in the region. In a way, the higher tambaqui production in the Northern Region of Brazil, with $73.10 \%$ of the national total (IBGE, 2019), explains this preference, as this fish is more abundant in the producing regions. The same effect was observed in this study, since the preference was for tilapia, the most produced species in Brazil as a whole (60\% of the total), with the state of Paraná as the leading producer (IBGE, 2019).

The decision to consume fish seems to be linked to the product's organoleptic characteristics, such as flavor and texture. As demonstrated by Kubitza (2002) and Silveira et al. (2012), both found the highest proportion of respondents selecting the preference for flavor as a decision for fish consumption. These data are in line with that reported in this study.

Other factors, such as protein quality, ease of digestion, and medical indication, also appear as having relative importance, but in different orders among the studies. The age of consumers seems to be involved in the decision, consumption frequency, and fish purchasing because there are reports of positive correlations between these variables (Maciel et al., 2012), probably due to the possible beneficial effects of fish meat consumption on individual health. This positive correlation between age and aspects of fish consumption and acquisition was also evidenced in this study.

In Brazil, the idea is that Brazilians do not consume fish because they are not used to it or do not have the habit due to the short supply (Pereira et al., 2003). However, the main factor cited as an impediment or disincentive to purchasing fish seems to be the price since respondents who do not consume or consume it less frequently cite this as a determining factor (Kubitza, 2002; Sonoda et al., 2012; Flores et al., 2014). Some studies cite price as an essential factor but not decisive at the time of purchase (Maciel et al., 2015), while others cite that price is irrelevant to this decision (Tavares et al., 2013).

Despite not having been directly evaluated as a possibly decisive factor in buying fish, in this study, the perception of the price charged by supermarkets was reported as being high, indicating that price can be a limiting factor for increased consumption. This perception was more significant for male consumers, a result that differs from Flores et al. (2014), who reported that women are the ones who most consider the price of fish high.
Fish filet was the most preferred by the interviewees; besides, there was a preference for purchasing these products fresh in supermarkets. Fornari et al. (2017) mentioned that the acquisition in supermarkets might be related to the concentration of food acquisition in a single place, thus avoiding trips to fairs or fishmongers. The preference for presentation in fillets is probably associated with practicality issues, for example, related to ease of preparation and the absence of thorns (Maciel et al., 2015; Lopes et al., 2016).

Gagleazzi et al. (2002) mentioned that sanitary and technological problems, in the sense of not finding fresh or good-looking products, negatively impact consumers' decision to purchase fish. Different studies corroborate the results obtained in this study regarding the evaluation of fish at the time of purchase (Silveira et al., 2012; Maciel et al., 2013, 2015); among the main attributes evaluated at the time of purchase are the odor, color, and texture, usually evaluated together; another aspect found in the literature cited, but not in this study, was the presence of the sanitary inspection seal.

From the point of view of possible contaminants and focusing mainly on mycotoxins, some studies demonstrate their presence in different fish species or cured fish. Tolosa et al. $(2014$; 2017) cite the presence of enniatins and beauvericins (emerging mycotoxins of the genus Fusarium spp.) in fresh fish from fish farms. Sun et al. (2015) found aflatoxin $B_{2}$, ochratoxin $A$, and zearalenone in fresh and cured fish in the Shanghai region of China. There are no evaluations of natural mycotoxin contamination in Brazil in both caught and farmed fish. The only contaminant residue evaluations are from experimental contamination.

In general, there is also a perception by consumers that the cooking process reduces the levels of chemical contaminants (Kabak, 2009; Tolosa et al., 2017). This may vary by mycotoxin type, with results showing that different heat treatment methods can reduce enniatins and beauvericins, but not more resistant mycotoxins such as aflatoxins (Tolosa et al., 2017).

Due to a bit of knowledge about mycotoxins (i.e., definitions and deleterious effects) being found in the population with up to IHS, it is possible to say that contact with fungi and mycotoxin information seems to happen only during CHS completion and later during higher education, probably because of disciplines such as biology. This, coupled with the fact that there is less information available about mycotoxin residue levels in fish and its derivatives, especially in Brazil, demonstrates the importance of greater control and investigation of this possible contamination, even if it is to demonstrate that there are no levels of these types of contaminants. Besides, it seems to disseminate information about these compounds through simple and accessible information to the less educated population because it is known that mycotoxins are present in several other types of food. 


\section{Conclusion}

Tilapia is the most consumed fish by supermarket customers in Curitiba, regardless of education and social class; this preference is due to the search for practicality in acquisition and preparation, unrelated to the purchase price. In general, consumers with a lower educational level showed a lack of knowledge about what mycotoxins are, their possible deleterious effects, and the possibility of their presence in fish.
This lack of knowledge and the fact that farmed fish are fed with feed that potentially carries these substances can result in a higher contamination risk to consumers through fish consumption.

Thus, it is suggested that more significant efforts should be taken to investigate and disseminate information related to this class of contaminants, providing a healthy and safe growth of this production chain.

\section{Contribution of authors:}

Anater, A.: Conceptualization, Methodology, Data acquisition, Data analysis, Writing, and Editing. Thon, B.M.: Data acquisition. Montanha, F.P.:

Conceptualization, Methodology, and Data acquisition. Weber, S.H.: Methodology and Data analysis. Ribeiro, D.R.: Data analysis, Writing, and Editing. Pimpão, C.T.: Data analysis, Writing, Editing, and Supervision.

\section{References}

Abd-Elghany, S.M.; Sallam, K.I., 2015. Rapid determination of total aflatoxins and ochratoxins a in meat products by immuno-affinity fluorimetry. Food Chemistry, v. 179, 253-256. https://doi.org/10.1016/j.foodchem.2015.01.140.

Associação Brasileira da Piscicultura (ABP). 2021. Anuário PeixeBR da Piscicultura - Produção de peixes de cultivo avança 5,9\% e atinge 802.930 t. ABP, Brasil.

Atayde, H.M.; Oliveira, I.M.A.; Inhamuns, A.J.; Teixeira, M.F.S., 2014. Fungos toxigênicos e micotoxinas na alimentação de peixes: Uma revisão. Scientia Amazonia, v. 3, (3), 59-71.

Barbosa, T.S.; Pereyra, C.M.; Soleiro, C.A.; Dias, E.O.; Oliveira, A.A.; Keller, K.M.; Silva, P.P.O.; Cavaglieri, L.R.; Rosa, C.A.R., 2013. Mycobiota and mycotoxins present in finished fish feeds from farms in the Rio de Janeiro State. International Aquatic Research, v. 5, 1-9. https://doi.org/10.1186/2008-6970-5-3.

Bombardelli, R.A.; Syperreck, M.A.; Sanches, E.A., 2005. Situação atual e perspectivas para o consumo, processamento e agregação de valor ao pescado. Arquivos de Ciências Veterinárias e Zoologia da UNIPAR, v. 8, (2), 181-195.

Flores, R.M.V.; Chicrala, P.M.; Soares, S.S., 2014. Avaliação das preferências dos consumidores de pescado do estado do Tocantins através de pesquisa de campo realizada no seminário caiu na rede é lucro. Brazilian Journal of Aquatic Science and Technology, v. 18, (1), 121-129. https://doi.org/10.14210/ bjast.v18n1.p121-129.

Food and Agriculture Organization (FAO). 2019. Fishery and aquaculture country profiles. The Federative Republic of Brazil. FAO, Rome.

Food and Agriculture Organization (FAO). 2020. The state of world fisheries and agriculture 2020 - sustainability in action. FAO, Rome.

Fornari, C.A.C.; Costa, R.P.B.; Pires, C.R.F.; Kato, H.C.A.; Sousa, D.N., 2017. Estudo sobre os hábitos alimentares e de consumo de pescado da população de Palmas (TO). Desafios, v. 4, (4), 136-142.

Gagleazzi, U.A.; Garcia, F.T.; Bliska, F.M.M.; Arima, H.K., 2002. Caracterização do consumo de carnes no Brasil. Revista Nacional da Carne, v. 27, (310), 35-46.

Gonçalves, A.A.; Passos, M.G.; Biedrzycki, A., 2008. Tendência do consumo de pescado na cidade de Porto Alegre: Um estudo através de análise de correspondência. Estudos Tecnológicos, v. 4, (1), 21-36.
Gonçalves, R.A.; Naehrer, K.; Santos, G.A., 2018. Occurrence of mycotoxins in commercial aquafeeds in Asia and Europe: A real risk to aquaculture? Reviews Aquaculture, v. 10, (2), 263-280. https://doi. org/10.1111/raq.12159.

Instituto Brasileiro de Geografia e Estatística - IBGE. 2017. (Accessed October 5, 2019) at: www.ibge.gov.br/estatisticas-novoportal/economicas/estatisticaseconomicas.html.

Instituto Brasileiro de Geografia e Estatística - IBGE. 2019. Produção da pecuária municipal 2018. IBGE, Rio de Janeiro, v. 46.

Instituto Brasileiro de Geografia e Estatística - IBGE. 2020. Pesquisa de orçamentos familiares - Avaliação nutricional da disponibilidade de alimentos no Brasil. IBGE, Rio de Janeiro.

Kabak, B., 2009. The fate of mycotoxins during thermal food processing. Journal of the Science of Food and Agriculture, v. 89, (4), 549-554. https://doi. org/10.1002/jsfa.3491.

Kubitza, F., 2002. Com a palavra, os consumidores. Panorama da Aquicultura, v. $69,48-53$.

Lopes, I.G.; Oliveira, R.G.; Ramos, F.M., 2016. Perfil do consumo de peixes pela população brasileira. Biota Amazônia, v. 6, (2), 62-65. http://dx.doi. org/10.18561/2179-5746/biotaamazonia.v6n2p62-65.

Maciel, E.S.; Savay-da-Silva, L. K.; Galvão, J. A.; Oetterer, M., 2015. Atributos de qualidade do pescado relacionados ao consumo na cidade de Corumbá, MS. Boletim do Instituto da Pesca, v. 41, (1), 199-206.

Maciel, E.S.; Savay-da-Silva, L.K.; Vasconcelos, J.V.; Sonati, J.G.; Galvão, J.A.; Lima, L.K.F, Oetterer, M., 2013. Relationship between the price of fish and its quality attributes: A study within a community at the University of São Paulo, Brazil. Journal of Food Science and Technology, v. 33, (3), 451-456. https://doi. org/10.1590/S0101-20612013005000059.

Maciel, E.S.; Vasconcelos, J.S.; Sonati, J.G.; Savay-da-Silva, L.K.; Galvão, J.A.; Oetterer, M., 2012. Perfil dos voluntários de universidade brasileira a respeito do consumo de pescado. Segurança Alimentar e Nutricional, v. 19, (1), 60-70. https://doi.org/10.20396/san.v19i1.8634669. 
Marijani, E.; Wainaina, J.M.; Charo-Karisa, H.; Nzayisenga, L.; Munguti, J.; Gnonlonfin, G.J.B.; Kigadye, E.; Okoth, S., 207. Mycoflora and mycotoxins in finished fish feed and feed ingredients from smallholder farms in East Africa. Egyptian Journal of Aquatic Research, v. 43, (2), 169-176. https://doi. org/10.1016/j.ejar.2017.07.001.

Mohamed, H.M.; Emeish, W.F.; Braeuning, A.; Hammad, S., 2017. Detection of aflatoxin-producing fungi isolated from Nile tilapia and fish feed. EXCLI Journal, v. 16, 1308. https://dx.doi.org/10.17179\%2Fexcli2017-960.

Montanha, F.P.; Anater, A.; Burchard, J.F.; Luciano, F.B.; Meca, G.; Manyes, L.; Pimpão, C.T., 2018. Mycotoxins in dry-cured meats: A review. Food and Chemical Toxicology, v. 111, 494-502. https://doi.org/10.1016/j.fct.2017.12.008.

Moutinho, F.F.B.; Nascimento, E.R.; Paixão, R.L., 2015. Percepção da sociedade sobre a qualidade de vida e o controle populacional de cães não domiciliados. Ciência Animal Brasileira, v. 16, (4), 574-588.

Olorunfemi, M.F.; Odebode, A.C.; Joseph, O.O.; Ezekiel, C.; Sulyok, M.; Krska, R.; Oyedele, A., 2013. Multi-mycotoxin contaminations in fish feeds from different agro-ecological zones in Nigeria. In: Agricultural Development Within the Rural-Urban Continuum. Tropentag, StuttgartHohenheim, Germany.

Organização das Nações Unidas (ONU). 2015. Transformando nosso mundo: a agenda 2030 para o desenvolvimento sustentável. ONU, Geneva (Accessed April 29, 2021) at: https://brasil.un.org/sites/default/files/2020-09/agenda2030pt-br.pdf.

Pereira, A.J.; Waszczynskyj, N.; Beirão, L.H.; Masson, M.L., 2003. Características físico-químicas, microbiológicas e sensorial da polpa de carpa prateada (Hypophthalmichthys molitrix) e dos produtos reestruturados. Alimentos e Nutrição, v. 14, (2), 211-217.
Petrie, A.; Watson, P., 2009. Estatística em ciência animal e veterinária. 2. ed. Roca, São Paulo, 248 pp.

Pietsch, C., 2020. Risk assessment for mycotoxin contamination in fish feeds in Europe. Mycotoxin Research, v. 36, (1), 41-62. https://doi.org/10.1007/s12550019-00368-6.

Silveira, L.S.; Abdallah, P.R.; Hellebrandt, L.; Barbosa, M.N.; Feijó, F.T., 2012. Análise socioeconômica do perfil dos consumidores de pescado no município de Rio Grande. Sinergia, v. 16, (1), 9-19.

Sonoda, D.Y.; Campos, S.K.; Cyrino, J.E.P.; Shirota, R., 2012. Demand for fisheries products in Brazil. Scientia Agricola, v. 69, (5), 313-319. https://doi. org/10.1590/S0103-90162012000500005.

Sun, W.; Han, Z.; Aerts, J.; Nie, D.; Jin, M.; Shi, W.; Zhao, Z.; Saeger, S.; Zhao, Y.; Wu, A., 2015. A reliable liquid chromatography-tandem mass spectrometry method for simultaneous determination of multiple mycotoxins in fresh fish and dried seafoods. Journal of Chromatography A, v. 1387, p. 42-48. https:// doi.org/10.1016/j.chroma.2015.01.071

Tavares, G.C.; Aquino, R.M.A.; Palhares, M.M.; Santos, R.R.D.; Bonfim, M.L.; Teixeira, L.V., 2013. Perfil do consumo de pescado na cidade de Belo Horizonte, MG. Boletim de Indústria Animal, v. 70, (3), 230-236. https://doi. org/10.17523/bia.v70n3p228

Tolosa, J.; Font, G.; Mañes, J.; Ferrer, E., 2014. Natural occurrence of emerging Fusarium mycotoxins in feed and fish from aquaculture. Journal of Agricultural and Food Chemistry, v. 62, (51), 12462-12470. https://doi. org/10.1021/jf5036838

Tolosa, J.; Font, G.; Mañes, J.; Ferrer, E., 2017. Mitigation of enniatins in edible fish tissues by thermal processes and identification of degradation products. Food and Chemical Toxicology, v. 101, 67-74. https://doi.org/10.1016/j.fct.2016.12.039 